\title{
Az új koronavírus okozta járvány első hullámának jellemzői és esetleges kapcsolata a tuberkulózis elleni oltottsággal
}

\author{
Emődy-Kiss Blanka - Pataki Ágnes - Deli Gábor - Papp Sándor \\ Mátyus Mária dr. - Fent János dr.
}

Magyar Honvédség Egészségügyi Központ, Védelem-egészségügyi Igazgatóság, Tudományos Kutató és Laboratóriumi Intézet, Budapest

\begin{abstract}
Bevezetés: A COVID-19-járvány az egész világon elterjedt. A járvány Európában való első megjelenése során megfigyelhető volt, hogy a terjedés mértéke kisebb azokban az országokban, ahol a tuberkulózis elleni védekezésül kiterjedt BCG-vakcinációt végeznek.

Célkitüzés: A jelen munkában olyan összefüggéseket igyekeztünk feltárni, amelyek befolyásolták a járványterjedés paramétereit, különös figyelemmel a BCG-vakcinációs gyakorlatra.

Módszerek: A világ összes olyan országára vonatkozóan, ahol megfelelő minőségű statisztikai adatok álltak rendelkezésünkre, vizsgáltuk a járvány terjedésének első hullámát. A mozgóátlagolt járványgörbéken elemeztük a járvány időtartamát, a tetőzés mértékét, a fertőzöttek és a halálesetek egymillió lakosra vetített számát. Figyelembe vettük az országok gazdasági mutatóit (GDP, légi forgalom, a tengeri hajózás mértéke).

Statisztikai analizis: A vizsgált paraméterek nem mutattak normális eloszlást, így nemparaméteres próbákkal (rangkorreláció, Kruskal-Wallis ANOVA) statisztikai kapcsolatot kerestünk a járványterjedés mértéke, a BCG-vakcináció és más paraméterek között.

Eredmények: A járvány gyorsan elterjedt a világon, de mégis, február első három hetében a terjedésben egy szünet volt megfigyelhető. A járványhullám Európában nagyjából egyszerre ért véget. A járvány által leginkább azok az országok érintettek, ahol nem alkalmaztak rendszeres BCG-vakcinációt, bár a képet bonyolítja, hogy ezek az országok gazdaságilag többnyire fejlettek. A halálozási rátában nem mutatkozott ilyen különbség.

Következtetés: Statisztikailag igazolható tény, hogy a vakcinációt végző országokból az első hullám alatt kevesebb fertőzöttet jelentettek; az ok-okozati összefüggés bizonytalan, hiszen az országok múltja, szokásai, társadalmi berendezkedése, gazdasági fejlettsége nem azonos. Eredményeink alátámasztják az összehasonlító kontaktkutatás fontosságát annak tisztázására, hogy a BCG-oltás hogyan befolyásolja az emberek vírussal szembeni érzékenységét, valamint a vírus terjesztésének, továbbadásának képességét.
\end{abstract}

Orv Hetil. 2021; 162(4): 123-134.

Kulcsszavak: SARS-CoV-2, COVID-19, tuberkulózis, BCG, járványterjedés

\section{A summary of characteristics of the first wave of new type coronavirus epidemic and potential association with tuberculosis vaccination}

Introduction: The new type of coronavirus (SARS-CoV-2) epidemic is widespread throughout the world. During the outbreak of the pandemic in Europe it was revealed that the rate of spread was lower in countries where extensive BCG vaccination is used to protect against tuberculosis.

Objective: In the present work, we sought to explore relationships that influenced epidemic spreading parameters, with particular reference to BCG vaccination practice.

Methods: We examined the first wave of the spread of the epidemic for all countries in the world where adequate quality statistics were available. We analyzed the duration of the epidemic, the extent of the peak, the number of infected people, and the number of deaths per million inhabitants with the moving average of epidemic curves. We took into account the economic indicators of the countries (GDP, air traffic and extent of maritime shipping). 
Statistical analysis: The examined parameters did not show a normal distribution, so we looked for a statistical relationship with non-parametric tests (rank correlation, Kruskal-Wallis ANOVA) between the extents of epidemic spread, BCG vaccination and other parameters.

Results: The epidemic spread rapidly around the world, but still, in the first three weeks of February, there was a pause in the spread. The first wave of epidemics ended roughly at the same time in Europe. Those countries are the most affected by the epidemic where regular BCG vaccination has not been used, although the picture is complicated by the fact that these countries are mostly economically developed. There was no such difference observable in the mortality rate.

Conclusion: Although this work clearly demonstrates that during the first wave of the pandemic, fewer infections were reported worldwide in countries where BCG vaccination is obligatory, however, the causal relationship is uncertain, as the countries' past, customs, social organization and economic development are different. Our results support the necessity of comparative contact tracing to clarify how BCG vaccination affects people's susceptibility to this new type of coronavirus as well as their ability to spread and transmit the virus.

Keywords: SARS-CoV-2, COVID-19, tuberculosis, BCG, spread of epidemic

Emődy-Kiss B, Pataki Á, Deli G, Papp S, Mátyus M, Fent J. [A summary of characteristics of the first wave of new type coronavirus epidemic and potential association with tuberculosis vaccination]. Orv Hetil. 2021; 162(4): 123134.

(Beérkezett: 2020. november 9.; elfogadva: 2020. november 27.)

\section{Rövidítések}

$\mathrm{ACE}=$ (angiotensin-converting enzyme) angiotenzinkonvertáló enzim; BCG = Bacille Calmette-Guérin; COVID-19 = (coronavirus disease 2019) koronavírus-betegség 2019; GDP $=$ (gross domestic product) bruttó hazai termék; NK-sejt $=$ (natural killer) természetes ölősejt; PCR $=$ (polymerase chain reaction) polimeráz-láncreakció; RNS = ribonukleinsav; SARS$\mathrm{CoV}-2=($ severe acute respiratory syndrome coronavirus 2$)$ súlyos akut légúti tünetegyüttest okozó koronavírus-2; tbc = tuberkulózis; $\mathrm{T}_{\mathrm{H}} \mathrm{l}$-sejtek = a sejtes immunválaszt elősegítő, l-es típusú helper T-sejtek; TMPRSS2 $=($ transmembrane protease, serine 2) transzmembrán szerin-proteáz-2; UK = (United Kingdom) Egyesült Királyság; USA $=$ (United States of America) Amerikai Egyesült Államok; WHO = (World Health Organization) Egészségügyi Világszervezet

A napjainkban dúló, SARS-CoV-2 által okozott betegség (COVID-19) a 2019. őszi megjelenése után világméretû járvánnyá nőtte ki magát. Szinte minden országot érintett, Magyarországot sem kímélte [1,2], mégis, már a járvány kezdeti szakaszában feltűnő volt, hogy az egyes országok érintettsége más és más. A jelenség mögött számos tényezőt lehetett sejteni, úgymint az országok eltéró éghajlati viszonyai, gazdasági fejlettsége, a kereskedelmi és turistaforgalom intenzitása, az életvitel sajátosságai (közlekedés, családszerkezet, az emberek érintkezési szokásai stb.), illetve az orvosi ellátórendszer jellemzői.

A SARS-CoV-2 a koronavírusok törzsébe tartozó, lipidburokkal rendelkező, állati eredetű, egyszálú RNS-vírus [3]. Elsősorban cseppfertőzéssel terjed, érzékeny detergensekre, száraz felületeken tönkremegy. A hőkezelést nem túri, bár újabb magyar vizsgálatok szerint a vírus ellenállóbb, mint korábban gondoltuk [4]. Erre mutat az is, hogy fagyasztott élelmiszerek felszínén sokáig fertőzőképes maradhat [5]. Emberre a 2019. év végén terjedt át. Azóta számos kládját különítették el, ismert mutációi közül különösen a 'spike' proteint (tüskefehérjét) érintő D614G-mutáció (a protein 614. aminosava aszparaginsavról glicinre változott) látszik jelentősnek [6].

A fertőzés során a vírus átjut a szervezet barrierjein, majd a 'spike' fehérjéje segítségével a leendő gazdasejt ACE2-receptorához kötődik - amit elősegít a neuropilin-1-hez való SARS-CoV-2-specifikus kötődés [7] -, és egy transzmembrán proteáz (TMPRSS2) segítségével bejut a sejtbe. Az ACE2 egy transzmembrán fehérje: nem tévesztendő össze az angiotenzinkonvertáló enzimmel (ACE), mely népszerú vérnyomáscsökkentő gyógyszerek támadáspontja. Az ACE2 más koronavírusok sejtbe való belépési pontjaként is szolgál [8], mely a tüdőn kívül megtalálható más szervekben is, ezzel magyarázva a koronavírus-fertőzés egyéb tüneteit [9].

A vírus jelenlétét PCR-módszerrel lehet igazolni a légutakból, esetleg székletből; az ehhez szükséges nukleinsav-szekvencia 2020 januárjától vált egységesen elfogadottá [10]. Ezért az első észlelés idôpontjának tekintetében lehet némi bizonytalanság az egyes országok esetében. A betegség kialakulása során termelődő ellenanyagokat szerológiai tesztekkel mutatják ki, de az eredmény ellentmondásos lehet [11-13].

Már a világjárvány kezdeti szakaszában megfigyelhető volt, hogy az egyes országok érintettsége más és más. Korán felmerült az a lehetőség, hogy kapcsolat áll fenn a különböző országok BCG- (Bacille Calmette-Guérin) vakcinációs gyakorlata és a COVID-19-járvány mortalitása között $[14,15]$. Ilyen kapcsolat elvileg nem zárható ki, hiszen a BCG-vakcina - emellett a kanyaró- és a gyermekbénulás-oltás is - erősíti a sejtes immunválaszt. Bár a 
pontos hatásmechanizmus nem ismert, gyakran említik az immunrendszer afféle trenírozását („trained immunity") mint lehetséges mechanizmust [16]. A vakcina több más kórokozóval szemben is $[17,18]$ aspecifikusan fokozza az immunválasz mértékét.

A tuberkulózis (tbc) egy olyan fertőző betegség, melyet a Mycobacterium tuberculosis komplexbe tartozó valamelyik Mycobacterium faj okoz. A saválló festődést mutató baktériumokat a szervezet immunrendszere nem képes hatékonyan elpusztítani, ezért krónikus fertőzöttség alakul ki. A Mycobacterium-fertőzés helyét a szervezet kötőszövettel veszi körül, de a baktériumok életben maradhatnak. A vesiculumokban élősködő Mycobacterium ellen a szervezet fó védekezési elemei a természetes immunitás oldaláról az aktivált makrofágok és az aktivált NK-sejtek, az adaptív immunitás oldaláról pedig a $\mathrm{T}_{\mathrm{H}} \mathrm{l}$ sejtek, melyek makrofágaktiváló citokintermeléssel járulnak hozzá a védekezéshez [19].

Robert Koch 1882-ben jelentette be a tbc baktériumának felfedezését $[20,21]$. Az ő tiszteletére 1982-ben a WHO március 24-ét a tuberkulózis világnapjának nevezte ki. A lille-i Pasteur Intézetben Albert Calmette és Camille Guérin 1908-ban kezdett foglalkozni a Lait Nocard által 1902-ben egy tbc-s tehén tőgyéből izolált virulens baktériumtörzzsel (M. bovis). A törzs 13 év alatt 231 passzázson ment keresztül, ez idő alatt elvesztette virulenciáját [22]. Az eredeti, Pasteur Intézetből származó BCG-törzset azóta világszerte különböző laborokban, különböző kondíciók mellett fenntartják és eredményesen használják [23, 24], ennek eredményeként ma már több mint 10-féle törzse létezik. Igaz, hogy az egyes törzsek hatékonysága nem teljesen azonos [25, 26]. A törzsek genetikai változatosságáról Zhang készített részletes, teljesgenom-szekvenáláson alapuló összefoglalót [27], feltárva, hogy bizonyos BCG-törzsekben nagyon sok, az immunválasz kiváltásáért felelős T-sejt-epitóp már hiányzik. Az általuk a 3. csoportba (Group 3) sorolt epitópok megléte vagy hiánya jellemző az egyes BCG-törzsekre. Például az eredeti Pasteur-, a dán, a prágai stb. törzsekben ezek hiányoznak, míg például a tokiói, orosz, svéd stb. törzsekben a Group 3 T-sejt-epitópok érintetlenül jelen vannak.

Magyarországon a tüdővész a múlt század elején népbetegség volt, nem véletlenül nevezték morbus hungaricusnak (a középkorban a kiütéses tífuszt is illették ezzel a névvel). A BCG-vakcinát 1936-ban, a gödöllői járásban alkalmazták először. Tömeges oltásokat azonban csak a Dán Vöröskereszt végzett országszerte, 1947-48-ban. 1953 óta az újszülöttek, 1959 óta ezenkívül a 3, 7, 10, 13, 17 és 20 éves, tuberkulinnegatív személyek tbc elleni BCG-védőoltása volt kötelező [28-30]. 1956 második felétôl az oltások már kétszeresre emelt csíraszámú vakcinával történtek [31]. Az ilyen módon a második világháború után rendszeressé tett BCG-vakcinációval, mely 15-20 évre, egyes tanulmányok szerint akár 40 évre védettséget nyújt a tbc-vel szemben $[32,33]$, sikerült ha- zánkban a tbc-t visszaszorítani. Ezért a magyar átoltottsági adatok - összehasonlítva a világ más országaival fontos adalékot szolgáltathatnak a COVID-19-járvány és a BCG-vakcinálás közötti kapcsolat tisztázásához.

Jelen cikkünkben a nyilvánosan hozzáférhető információk feldolgozásával, több, nem csak európai ország adatainak összehasonlításával próbáltuk kideríteni, hogy van-e kapcsolat a BCG-átoltottság és a járvány jellemzői között, magyarázható-e ezzel, hogy Európa bizonyos országai kevésbé érintettek, illetve foglalkozunk azokkal a faktorokkal is, amelyek a járvány terjedésében közrejátszhatnak. Vizsgálataink a járvány elsődleges hullámára, a 2020. július 1. előtti szakaszra vonatkoznak.

\section{Módszerek}

\section{Adatforrások}

A különböző országokra vonatkozó alapadatok és az egyéb, kiegészítő információk az 1. táblázatban feltüntetett forrásokból származnak. Az adatok elemzését 2020. július 1-jével zártuk le.

\section{Az elemzésbe bevont országok}

Az elemzésbe azokat az országokat vontuk be, amelyekról adatokat közöltek az esetszámra, illetve halálozásra vonatkozó források (a Johns Hopkins Egyetem adatbázisa: 1. és 2. adatforrás), és amelyek eleget tettek az alábbi kritériumoknak:

- Az ország lakossága meghaladja az 500000 fót (ezzel kizártunk néhány városállamot, ritkán lakott területet, ahol a járványterjedés minden bizonnyal jelentősen eltér a többi országétól).

- Valóban egy országról van szó. Kizártuk az adatok között szereplő néhány hajót. Ugyanakkor Kína, Kanada, Ausztrália és az USA adatait nem összesítve, hanem tartományonként (területenként, államonként) vettük figyelembe. Oroszországot - noha területe indokolná a részekre bontást - egy országként kezeltük, mivel az egyes részterületeire vonatkozóan nem leltünk fel adatokat.

További feltételként szabtuk meg - de csak bizonyos elemzések esetében - az alábbiakat:

- A járványgörbe elfogadható minőségú. Ez a kritérium meglehetősen szubjektív, de kizártuk azokat az országokat, ahol az adatokban nem értelmezhető ugrások voltak megfigyelhetők, vagy más, az értékelhetőséget megkérdőjelező eltérés látszott (például kirívóan alacsony esetszám).

- A járványgörbe maximuma megítélhető. Néhány kínai tartomány esetében már csak a járványgörbe leszálló szárára vonatkozóan vannak adatok, így ezeket kizártuk. 


\begin{tabular}{|c|c|c|}
\hline \multicolumn{3}{|c|}{ Alapadatok } \\
\hline Sorszám & Az adat neve & Az adat forrása \\
\hline 1. & $\begin{array}{l}\text { Esetszám - PCR-teszttel pozitívnak bizonyuló } \\
\text { esetek lejelentett száma napi bontásban }\end{array}$ & \multirow{2}{*}{$\begin{array}{l}\text { A Johns Hopkins Egyetem által közzétett adatsorok, melyek a WHO, CDC, } \\
\text { ECDC, az egyes államok, országok népegészségügyi hivatalai adatain és más, } \\
\text { hivatalosnak tekinthető adatforrásokon alapulnak (ezek részletes listája a honlapon } \\
\text { megtalálható): } \\
\text { https://coronavirus.jhu.edu/map.html }\end{array}$} \\
\hline 2. & $\begin{array}{l}\text { A halálozások száma - A COVID-19- } \\
\text { betegséggel összefüggésben meghalt, } \\
\text { bejelentett halálesetek száma napi bontásban }\end{array}$ & \\
\hline 3. & BCG-átoltottsági adatok & $\begin{array}{l}\text { 'BCG Atlas' - BCG-átoltottsági interaktív térkép: } \\
\text { http://www.bcgatlas.org/index.php }\end{array}$ \\
\hline 4. & $\begin{array}{l}\text { Újszülöttek BCG-átoltottsági adatai } \\
\text { (1985-tól) }\end{array}$ & $\begin{array}{l}\text { https://apps.who.int/immunization_monitoring/globalsummary/timeseries/ } \\
\text { tswucoveragebcg.html }\end{array}$ \\
\hline 5. & Demográfiai adatok & $\begin{array}{l}\text { Worldometer-adatbázis: } \\
\text { https://www.worldometers.info/world-population/population-by-country/ }\end{array}$ \\
\hline 6. & $\begin{array}{l}\text { A Magyarországon koronavírus-fertőzésben } \\
\text { elhunytak életkora és neme }\end{array}$ & $\begin{array}{l}\text { A magyar hivatalos koronavírus-honlapon (https://koronavirus.gov.hu) közzétett } \\
\text { esetszintű adatok }\end{array}$ \\
\hline 7. & Magyar halálozási statisztikai adatok & $\begin{array}{l}\text { A KSH (Központi Statisztikai Hivatal) honlapján múködő, lekérdezéssel nyert } \\
\text { országos halálozási statisztikák a 2018. év összhalálozásának életkor és nem } \\
\text { szerinti csoportosításban }\end{array}$ \\
\hline \multicolumn{3}{|c|}{ Egyéb források } \\
\hline 8. & Kládok, vírustörzsek & $\begin{array}{l}\text { A SARS-CoV-2 eddig kategorizált kládjai és a vírustörzsek genetikai adatai. } \\
\text { A kládbesorolás idővel megváltozik, a friss adatok az alábbi honlapról kérdezhetők } \\
\text { le. A teljes adatbázis nem férhető hozzá. } \\
\text { https://nextstrain.org/ncov/global:c=clade_membership\&l=radial }\end{array}$ \\
\hline 9. & A repülőterek éves forgalmi adatai & $\begin{array}{l}\text { A világ nagy repülőterein évente megforduló utasok száma: } \\
\text { https://en.wikipedia.org/wiki/Category:Lists_of_airports_by_country }\end{array}$ \\
\hline 10. & Teherhajózás & $\begin{array}{l}\text { A hajóval szállított áruk éves mennyisége a világ nagy kikötőire vonatkozóan: } \\
\text { https://en.wikipedia.org/wiki/List_of_busiest_container_ports }\end{array}$ \\
\hline 11. & A napsütéses órák száma (óra/év) & $\begin{array}{l}\text { Az adott országban a napsütéses órák átlagos száma egy évre vetítve: } \\
\text { https://en.wikipedia.org/wiki/List_of_cities_by_sunshine_duration }\end{array}$ \\
\hline 12. & GDP (USD) & $\begin{array}{l}\text { Az egyes országok éves bruttó nemzeti össztermelése USD-ban kifejezve: } \\
\text { https://en.wikipedia.org/wiki/List_of_countries_by_GDP_(PPP)_per_- } \\
\text { capita\#cite_note-IMF-6 } \\
\text { https://data.worldbank.org/indicator/NY.GDP.PCAP.PP.CD?most_recent_va- } \\
\text { lue_desc=true }\end{array}$ \\
\hline
\end{tabular}

BCG = Bacille Calmette-Guérin; CDC = Járványügyi és Betegségmegelőzési Központ (Egyesült Államok); COVID-19 = koronavírus-betegség 2019; ECDC = Európai Betegségmegelőzési és Járványvédelmi Központ; GDP = bruttó hazai termék; KSH = Központi Statisztikai Hivatal; PCR = polimeráz-láncreakció; SARS-CoV-2 = súlyos akut légúti tünetegyüttest okozó koronavírus-2; USD = amerikai dollár; WHO = Egészségügyi Világszervezet

\section{A BCG-átoltottság mértéke}

Kiemelten foglalkoztunk a BCG-átoltottsággal. Sajnos erre vonatkozóan nem minden ország esetében állnak rendelkezésre korrekt felmérésen alapuló, számszerú adatok, ezért ilyen esetben a teljes lakosság átoltottsági százaléka nem adható meg. Ez többnyire azokra az országokra jellemző, ahol nincs szigorú, követhető oltási rend, és emiatt feltételezhető, hogy a lakosságnak csak kis hányada kapta meg a BCG-vakcinát.

Egy lehetséges megközelítésként két alapkategóriát állítottunk fel a gyerekek, illetve a felnőttek átoltottságára vonatkozóan. A gyerekpopulációt akkor tekintettük átoltottnak, ha a 2009-2018-as időszakban az átoltottság átlaga meghaladta a $75 \%$-ot (a 4 . forrás alapján). A felnőtteket akkor, ha 2009 előtt volt olyan időszak - jel- lemzően legalább egy évtized -, amikor országosan kötelező volt a védőoltás. Bár ezek a kategóriák nem tökéletesek, hiszen nem veszik figyelembe a 11-18 éves korosztályt, továbbá a 2 éves kor alattiakat, illetve nem vizsgáltuk azt sem, hogy történt-e újraoltás valamelyik életkorban. Mégis ez a rendszerezés a gyakorlatban jól használhatónak tûnik, az országok ennek alapján három csoportba sorolhatók: 1) nincs és nem is volt rendszeres oltás; 2) már régóta oltják a gyermekeket, a ma már felnőttek is jellemzően megkapták az oltást; 3 ) a felnőttek átoltottak, de a kötelező vakcinálást néhány évtizede abbahagyták. Érdekes megállapítani, hogy a negyedik lehetséges kategória hiányzik, vagyis nincs olyan ország, ahol az oltást az utóbbi évtizedben vezették volna be. A szovjet és a jugoszláv utódállamok oltásának kezdetét - ha pontos adat nem állt rendelkezésre - 1955-re, illet- 
ve 1946-ra becsültük. Sajnos így is 37, egyéb szempontból értékelhető ország esetében nem sikerült megbízható adatot fellelni a felnőttek oltottságára vonatkozóan. Ezeket az országokat a BCG-vel kapcsolatos vizsgálatokból kihagytuk.

Az egyes országokat aszerint csoportosítottuk, hogy az ott alkalmazott BCG-vakcinák - Sala és mtsai munkáját [34], valamint a 3 . forrás adatait alapul véve - hordozzák-e a Group 3 T-sejt-epitópokat (nem mutálódott, tehát G3-) vagy sem (G3+).

\section{A járványgörbe jellemzőinek megállapitása}

$\mathrm{Az}$ adatok értelmezését segítendő, az 1 ábrán néhány ország járványgörbéje látható. Az országok lakosságszáma közötti különbség miatt a függőleges tengelyen az 1 millió lakosra jutó új esetszám van feltüntetve. A véletlenszerú napi ingadozást egy 7 napos időszakra vonatkozó mozgóátlagolással igyekeztünk csökkenteni. A statisztikai számítások során is az 1 millió fơre vetített, 7 napos mozgóátlagértékeket vettük figyelembe. Jól megfigyelhető, hogy a járvány az egyes országokat különböző időpontokban érte el, például Dél-Koreát jóval hamarabb, mint Namíbiát. A járvány kezdetének az elsó jelentett eset dátumát tekintettük az adott országban. A grafikonon jól látszik a görbe maximuma (a járvány tetőzése) azokban az országokban, ahol a járvány már lecsengóben van (például Magyarország vagy DélKorea), másutt a maximális érték a vizsgált időszak végén van, ezekben az országokban a járvány még további erősödése várható (például Namíbia). Az ilyen országokat a maximumérték szempontjából - mivel az még nem állapítható meg - kihagytuk a statisztikai elemzésből. $\mathrm{Az}$ így meghatározott maximumérték sajátos előnye, hogy miután a járvány elérte tetőpontját, ez a paraméter már nem változik tovább, hacsak újabb nagy járványhullám nem alakul ki. Magyarország vonatkozásában az így

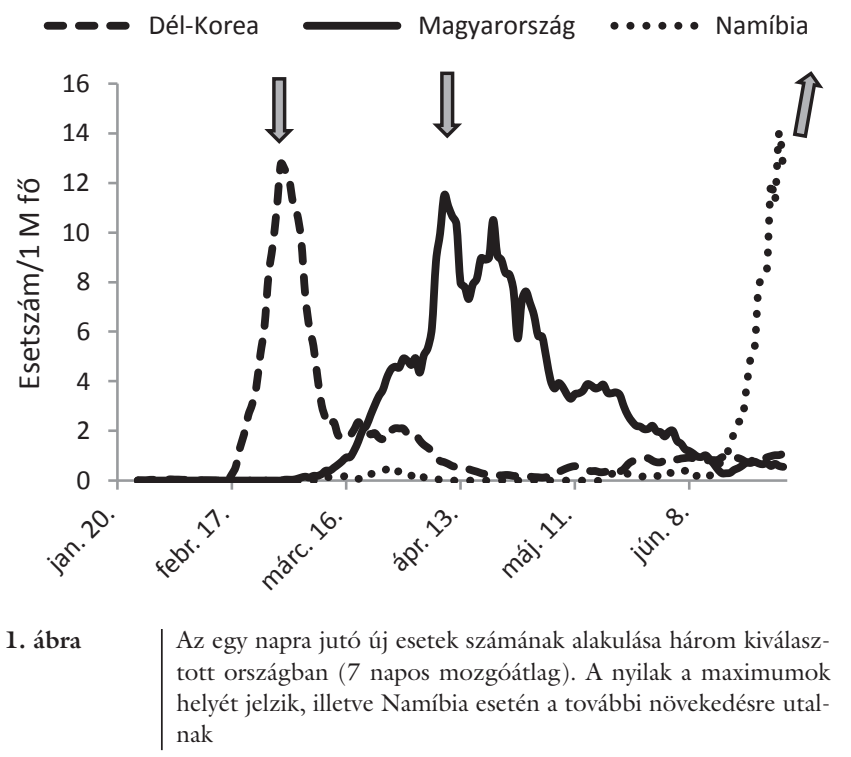

számolt maximum 11,49 eset/1 millió lakos, ami 2020. 04. 09-én következett be. (A tényleges adatok maximuma ettől kissé eltér a napi szóródás miatt; ezen a napon: 85 megbetegedés/9 660351 fő.) Minden országra értelmezhető adat viszont a vizsgált időintervallum végére (2020. 07. 01.) elért kumulatív esetszám.

A halálozási adatokra vonatkozóan ugyanezen paramétereket vizsgáltuk.

\section{Egyéb jellemzők}

Az országban élő összlakosság számát az 5. forrásból, az egy före jutó nemzeti összterméket (GDP - USD/fó) a 12. forrásból, a napsütéses órák számát a 11 . forrásból, az utasforgalomra vonatkozó adatokat a 9. és 10. forrásból vettük.

\section{A halálozás életkor szerinti megoszlása}

Abból az elképzelésből kiindulva, hogy a BCG-vakcináció tömeges bevezetésének időpontja visszaköszönhet az idősebbek megbetegedési és halálozási arányában, megvizsgáltuk a koronavírus-járvány okozta halálozás életkor szerinti megoszlását (a 6 . forrás adatai), összevetve az 1 évvel korábbi időszak - még biztosan nem koronavírus okozta - magyarországi haláleseteinek koreloszlásával (a 7. forrás adatai). Sajnos ilyenfajta koreloszlást csak Magyarország esetében tudtunk tanulmányozni. Az ábrákon az összehasonlítás végett többnyire százalékos arányokat adunk meg, de a statisztikai próbákat a vonatkozó nyers adatokon végeztük el.

A fertőzöttek számára vonatkoztatott halálozási arány pontos megállapítása nem lehetséges a járvány vége előtt. Két becslést próbáltunk adni ennek mértékére: egyfelől a vizsgált utolsó napon, tehát 2020. 07. 01-jén számítottuk az összes koronavírus-haláleset számának arányát az addigi kumulatív esetszámhoz viszonyítva, másfelől a halálozási görbe maximális értékének arányát számoltuk a napi esetszám maximumához viszonyítva az egyes országokban a mozgóátlagolt görbék alapján. (Bár ez utóbbi adatpár nem ugyanarra a napra vonatkozik, megítélésünk szerint mégis jól jellemzi a halálozási rátát, pont amiatt, mert a halálesetek késnek a pozitivitás kimutatásához képest.)

\section{Statisztikai elemzés}

Az általunk vizsgált összes változóról megállapítható, hogy eloszlásuk szignifikánsan eltér a Gauss-féle normáleloszlástól (Shapiro-Wilk-teszt), ezért kizárólag nemparaméteres statisztikai vizsgálatokat végeztünk: két csoport összehasonlítására a Mann-Whitney-féle rangösszegtesztet, több csoport összehasonlítására az egyutas Kruskal-Wallis-próbát. A szignifikanciaszintet $\mathrm{p}<0,05$ értékben állapítottuk meg. A szignifikanciát okozó cso- 
port elkülönítésére a Dunn-féle post-hoc tesztet alkalmaztuk.

Bizonyos csoportokba tartozó elemszámok összehasonlítására a khi-négyzet-próbát használtuk. A statisztikai próbákat a SigmaStat program 12.3-as verziójával (Systat Software, Inc., San Jose, CA, USA) végeztük.

Mozgóátlagoláson az egyszerü, hétnapos intervallumra kiterjedő mozgóátlagolást értjük, mely adatot az intervallum közepéhez rendeltük hozzá.

\section{Eredmények}

\section{A járvány kezdetépel kapcsolatos megfigyelések}

A 2. ábra a járvány kezdetének időbeliségét ábrázolja, figyelembe véve az észlelt első megbetegedés és az elsó haláleset időpontja között eltelt időt is (a függőleges tengelyen). Jól megfigyelhető egy szünet február első három hetében, amikor is alig volt olyan ország, ahol ekkor kezdődött volna a járvány. Az első halálozás bejelentett időpontjának eloszlását tekintve is hasonló jelenség figyelhető meg február 21. és 29. között (ezt ábrán nem mutatjuk be). Igaz, ennek időtartama rövidebb, a halálesetek eloszlása időben elhúzódóbb.

A 2. ábrán további furcsaságok is megfigyelhetők. Az országok 4 csoportra különülnek el (2. táblázat). Az I. (például Kína, Franciaország) és a III. (például Magyarország, Ausztria) csoportban az első pozitív eset és az első haláleset közötti időtartam viszonylag rövid (medián: 17 és 14 nap), míg a II. (például Németország, India) és a IV. (például Ruanda, Dél-Szudán) csoportban jóval hosszabb (medián: 48 és 40 nap). Továbbá, az

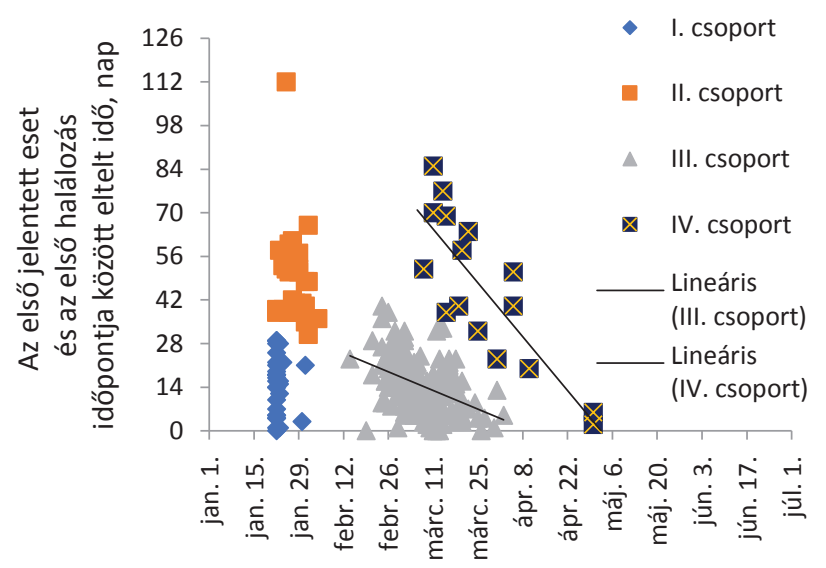

A jelentett első eset dátuma

\footnotetext{
2. ábra $\quad$ Az első haláleset és az első bejelentett megbetegedés között eltelt napok száma az első megbetegedés dátumának függvényében. Az országok 4, jól látható csoportra különülnek el A csoportokon belül az országokat közel egyidejúleg érte el a járvány első hulláma, de az első halálesetet bejelentésének időbeli késése tovább árnyalja a képet. Az egyes csoportokba sorolt országokat különböző szimbólumokkal tüntettük fel. Az időbeliséget tükröző csoportokat római számokkal jelöltük. Megfigyelhetjük, hogy februárban megtorpant a járvány terjedése a II. és a III. csoport között
}

I. csoport kivételével (ahol a járvány már az első vizsgált napon is javában zajlott, de nincs pontos adat az elsó észlelt eset dátumáról) megfigyelhető egy csökkenő tendencia: minél később indult a járvány, annál rövidebb idő telt el az első haláleset bejelentéséig. Ez a tendencia a III. és a IV. csoportban erősen szignifikáns (Spearman-féle rangkorreláció: $\mathrm{p}<0,001)$.

Ha a járvány tetőzésének dátumát (vagyis amikor a legmagasabb a napi esetszám) vizsgáljuk, feltúnő, hogy

2. táblázat Néhány példa az egyes csoportokba tartozó országokra a 2. ábra szerinti országcsoportok és a BCG-átoltottság összefüggésében

\begin{tabular}{|c|c|c|c|}
\hline & $\begin{array}{l}\text { Sem a gyermekek, } \\
\text { sem a felnőttek } \\
\text { nincsenek oltva }\end{array}$ & $\begin{array}{l}\text { A felnőttek } \\
\text { oltva vannak, } \\
\text { a gyermekek } \\
\text { már nem }\end{array}$ & $\begin{array}{l}\text { A felnőttek és } \\
\text { a gyermekek is } \\
\text { oltva vannak }\end{array}$ \\
\hline \multirow{3}{*}{$\begin{array}{l}\text { I. ország- } \\
\text { csoport }\end{array}$} & Olaszország & Franciaország & Japán \\
\hline & & & Dél-Korea \\
\hline & & & Kína \\
\hline \multirow[t]{8}{*}{$\begin{array}{l}\text { II. ország- } \\
\text { csoport }\end{array}$} & $\begin{array}{l}\text { Kanada egyes } \\
\text { részei }\end{array}$ & $\begin{array}{l}\text { Ausztrália egyes } \\
\text { részei }\end{array}$ & $\begin{array}{l}\text { Kína - Belső- } \\
\text { Mongólia }\end{array}$ \\
\hline & $\begin{array}{l}\text { Az USA egyes } \\
\text { részei }\end{array}$ & Belgium & Oroszország \\
\hline & & Finnország & Thaiföld \\
\hline & & Németország & \\
\hline & & India & \\
\hline & & Spanyolország & \\
\hline & & Svédország & \\
\hline & & $\begin{array}{l}\text { Egyesültt } \\
\text { Királyság }\end{array}$ & \\
\hline \multirow[t]{13}{*}{$\begin{array}{l}\text { III. ország- } \\
\text { csoport }\end{array}$} & $\begin{array}{l}\text { Kanada egyes } \\
\text { részei }\end{array}$ & $\begin{array}{l}\text { Ausztrália egyes } \\
\text { részei }\end{array}$ & Örményország \\
\hline & $\begin{array}{l}\text { Az USA egyes } \\
\text { részei }\end{array}$ & Ausztria & $\begin{array}{l}\text { Fehérorosz- } \\
\text { ország }\end{array}$ \\
\hline & Ciprus & $\begin{array}{l}\text { Bosznia- } \\
\text { Hercegovina }\end{array}$ & Brazília \\
\hline & Libanon & Dánia & Bulgária \\
\hline & & Írország & Horvátország \\
\hline & & Izrael & Csehország \\
\hline & & Új-Zéland & Észtország \\
\hline & & Norvégia & Magyarország \\
\hline & & Szlovákia & Irán \\
\hline & & Szlovénia & Lengyelország \\
\hline & & $\begin{array}{l}\text { Dél-afrikai } \\
\text { Köztársaság }\end{array}$ & Románia \\
\hline & & Svájc & Szaúd-Arábia \\
\hline & & Ukrajna & Törökország \\
\hline \multirow[t]{5}{*}{$\begin{array}{l}\text { IV. ország- } \\
\text { csoport }\end{array}$} & $\begin{array}{l}\text { Kanada egyes } \\
\text { részei }\end{array}$ & Francia Guyana & Ruanda \\
\hline & & Új-Kaledónia & Sierra Leone \\
\hline & & $\begin{array}{l}\text { Montserrat } \\
\text { (sziget) }\end{array}$ & Tádzsikisztán \\
\hline & & $\begin{array}{l}\text { Brit Virgin- } \\
\text { szigetek }\end{array}$ & \\
\hline & & Dél-Szudán & \\
\hline
\end{tabular}

BCG = Bacille Calmette-Guérin 
sok országban egyszerre fordult meg a járvány (a 2020. március 2l. utáni három hétben), attól függetlenül, hogy mikor kezdődött. Meg kell jegyezni azonban, hogy a 2. ábra szerinti mind a négy csoportban találhatók olyan országok, ahol a tetózés jóval később következett be, azaz a járvány felfutása jóval hosszabb ideig tartott. Ebbe az elemzésbe csak azokat az országokat tudtuk bevonni, ahol a tetőzés már lezajlott, annak dátuma egyértelmüen megadható.

Ugyanakkor nincs kapcsolat a járvány felfutásához szükséges idő és a járvány által érintettek száma - legalábbis ezt 2020. július 1-jén vizsgálva - között. Ugyanilyen eredményt ad, ha a járvány tetőzéséig elért összes eset számát vizsgáljuk, illetve hasonlóképpen viselkednek a halálozásra vonatkozó adatok is. (Ezeket nem mutatjuk be.)

\section{A BCG-oltás és a járvány kezdetének kapcsolata}

A 3. ábráról az olvasható le, hogy mennyire jellemző az egyes országcsoportokban a BCG-vakcinával való átoltottság. Külön-külön vizsgálva a gyermekek, illetve a felnőttek átoltottságával való kapcsolatot, az I. csoport jól elkülönül ugyan, de a II-IV. csoport között már nincs különbség abban a tekintetben, hogy milyen arányban kerülnek ezekbe a csoportokba olyan országok, ahol magas az átoltottság. Ha a módszerek között taglalt, BCGoltottság szerinti hármas csoportosítással élünk, akkor is hasonló eredményeket látunk, bár itt már a II-IV. csoport sem tekinthető homogénnek az átoltottság szerint (khi-négyzet: 11,4, p =0,02). A 3. ábra adatainak értelmezéséhez fontos tisztában lenni azzal, hogy a vizsgált országok száma az egyes csoportokban jelentősen eltérő. A legtöbb ország a III. csoportba tartozik (109 ország), míg a legkevesebb a IV. csoportba (mindössze 6).

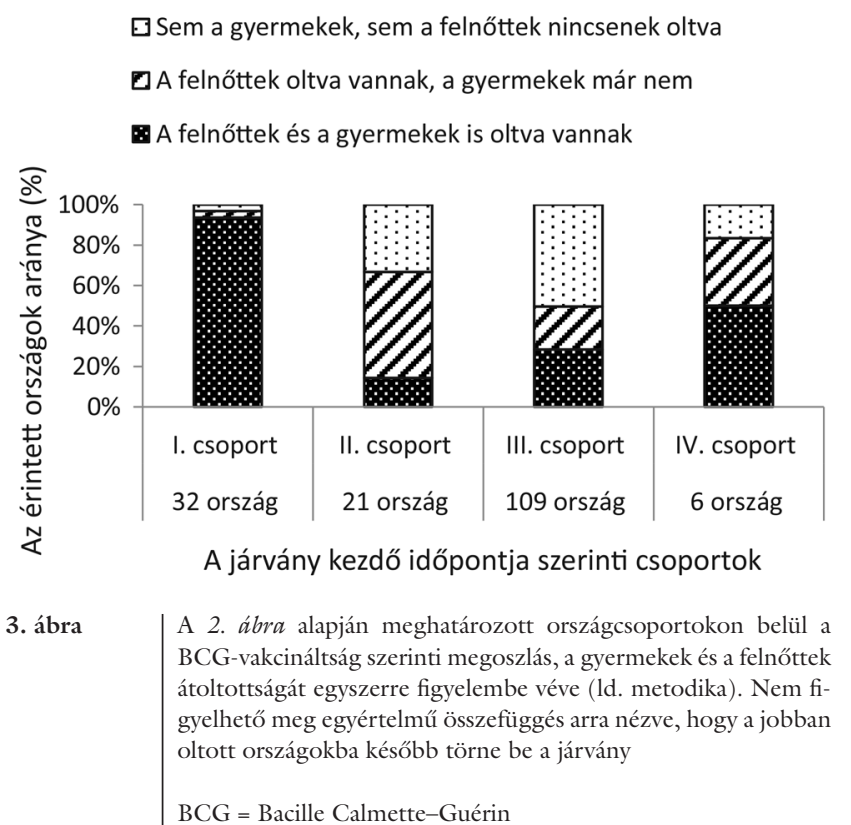

\section{A BCG-oltás és a járvány kiterjedtségének kapcsolata}

Mivel az egyes országokban a járvány más-más stádiumban van, a járvány kiterjedtségét még nem lehet megítélni pontosan. A járványgörbe bizonyos paraméterei mégis jó becslést adhatnak a járvány súlyosságára. Ezek a paraméterek: a napi esetszám maximális értéke, az ennek időpontjáig bekövetkező összes eset, illetve a vizsgált időszak végéig, vagyis 2020 . július 1 -jéig bekövetkezett összes eset száma, illetve ugyanezen értékek a halálesetekre vonatkoztatva. Minden ilyen paramétert l millió lakosra vetítve értelmezünk.

A járvány súlyosságát jellemző értékeket nem befolyásolja sem az, hogy az I-IV. csoport melyikébe tartozik az ország, sem az, hogy mennyi ideig tartott a járvány kibontakozása.

Ha az országok BCG-átoltottság szerinti három csoportját vizsgáljuk, akkor megfigyelhetjük, hogy azokban az országokban, ahol sem a gyermekek, sem a felnőttek
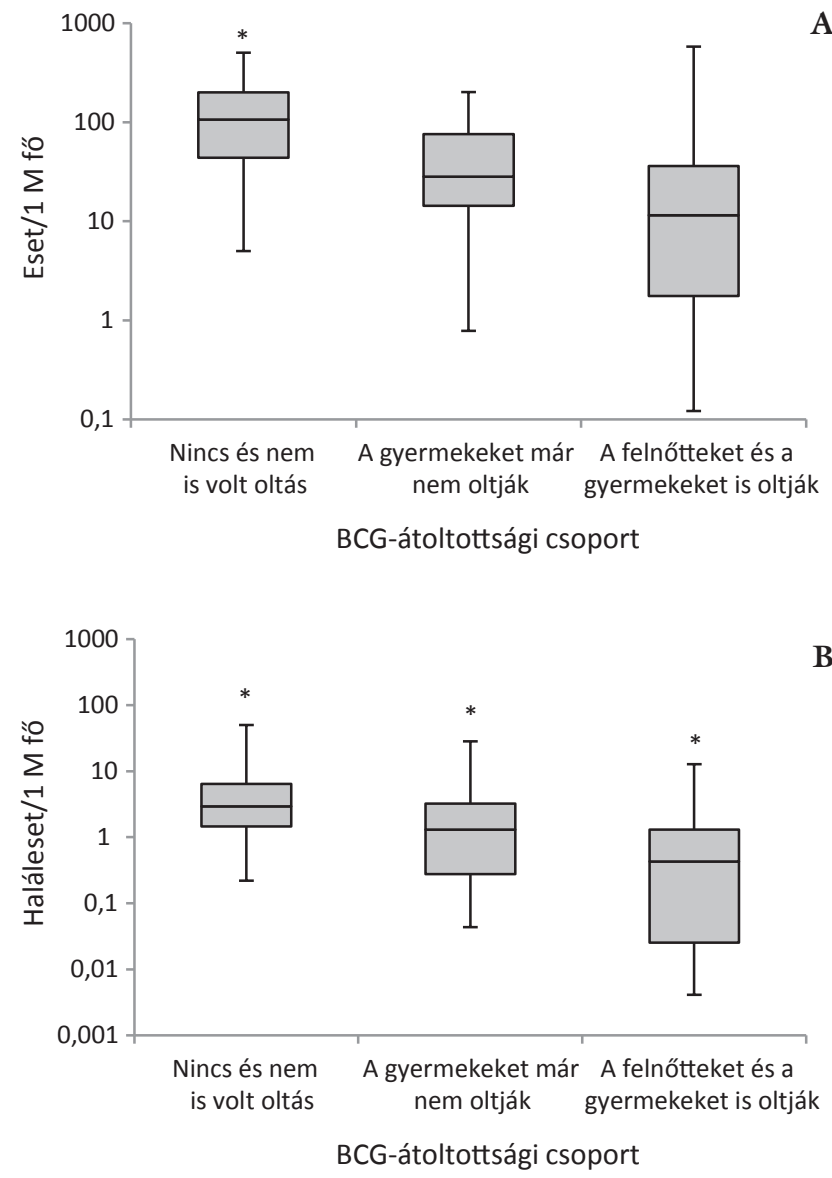

4. ábra $\mid$ Az ábra bemutatja, hogy a gyermekek és a felnőttek BCG-átoltottsága szerint csoportosított országokban hogyan alakult a járvány által érintett fertőzöttek száma (A), illetve a halálozási szám (B) 1 millió lakosra vetítve

*: A jelölt csoportok szignifikánsan $(\mathrm{p}<0,05)$ eltérnek a többitől (Dunn-teszt)

BCG $=$ Bacille Calmette-Guérin 
nincsenek átoltva, szignifikánsan magasabbak a járvány súlyosságát jellemző paraméterek. A 4/A ábrán-ezt reprezentálandó - a járvány tetőfokán elért maximális napi esetszámot tüntettük fel l millió lakosra vonatkoztatva. A BCG-oltást sem most, sem korábban rendszeresen nem alkalmazó országokban szignifikánsan magasabb értéket kapunk (Kruskal-Wallis ANOVA, p<0,05, Dunn posthoc teszt, p<0,05). A 4/B ábra a halálesetekre vonatkozóan mutatja ugyanezt. A vizsgált paraméterek közül ebben az egy esetben tapasztaltuk, hogy mindhárom csoport eltér a többitől a post-hoc teszt alapján $(\mathrm{p}<0,05)$. Az egyéb esetekben a szignifikancia okozójának az az országcsoport azonosítható, ahol a lakosságot a BCG-vel egyáltalán nem oltották. Az ábrákon a mediánt, a kvartiliseket, valamint a minimumot és maximumot ábrázoltuk.

A BCG-vakcina G3-mutáció szerinti fajtáját vizsgálva az 5. ábrán (bal oszlopsor) látható az egyetlen szignifikáns különbség, azaz a G3+ típussal vakcináló országokban magasabb az 1 millió lakosra jutó legnagyobb napi esetszám. Ez a szignifikancia eltúnik (jobb oldali oszlopsor) a teljes átoltottságú országokban.

Az árnyaltabb kép kialakítása érdekében megvizsgáltuk továbbá, hogy a 2. ábra szerinti I-IV. csoportba tartozó, illetve a BCG-vakcináció tekintetében eltérő országok vajon más jellemzőkben is eltérnek-e egymástól. Az országcsoportok között feltúnő, hogy az I. és a II. csoportban a légi forgalom kiemelkedően magas, a hajózás is fejlett, viszont a napsütéses órák száma nem tér el. A BCG szerinti csoportosítás esetén azt tapasztaltuk, hogy nincs különbség sem a napsütéses órák száma, a repülőterek forgalma, sem a hajózási jellemzók tekintetében. (Ezeket ábrán nem mutatjuk be.) Egyetlen különbséget fedeztünk fel: azokban az országokban, ahol sem a gyermekek, sem a felnőttek rendszeres vakcinációját nem végezték (például USA, Kanada), jellemzően magasabb az egy före jutó nemzeti össztermék (GDP) nagysága.

\section{A halálozással kapcsolatos észrevételek}

A magyar kormány által létrehozott operatív törzs nyilvánosságra hozta honlapján a koronavírus-betegségben elhunytak nemét, életkorát és legfontosabb társbetegségeit - természetesen név nélkül. A 2020. július 1-jéig bekövetkezett koronavírus-halálesetek életkormegoszlását a 6. ábra mutatja be az összes haláleset százalékában. Ugyanezen a diagramon látható az 1 évvel korábbi (2018) magyarországi halálesetek életkormegoszlása is. A két grafikon bár hasonló, mégis szignifikánsan különbözik egymástól (khi-négyzet-próba: p<0,001). A férfi : nő arányban sincs szignifikáns különbség (97\% vs. 95\%, khi-négyzet-próba: p = 0,84). Ugyancsak megfigyelhető az ábrán a 65 év felettiek fokozott érintettsége a koronavírus-fertőzésben ( $89 \%$ vs. $78 \%$, khi-négyzetpróba: $\mathrm{p}<0,001)$.

Bár életkormegoszlási adataink sajnos nincsenek, a vizsgált nemzetközi halálozási ráták egyikében sem találtunk szignifikáns különbséget sem a BCG-oltottsági csoportok, sem az alkalmazott BCG-vakcina típusa, sem pedig a 2. ábrán bemutatott országcsoportok szerint, noha két becslés jó korrelációban áll egymással (Spearman-féle rangkorrelációs együttható: $\mathrm{R}=0,93$ ).

\section{Megbeszélés}

Az országokat a 2. ábra szerint, a járvány kitörése és az első haláleset időpontja alapján csoportosítva kiderül, hogy az I. csoportot alapvetően a kínai tartományok alkotják, néhány környékbeli országgal együtt. Ide került azonban Franciaország és Olaszország is, mutatva, hogy a vírus nagyon korán eljutott Európába is. Egyes tudósítások [35] korábban más célból levett minták utólagos elemzésére hivatkozva állítják, hogy a vírus már a 2019. év végén jelen volt Európában. Az ábra alapjául szolgáló

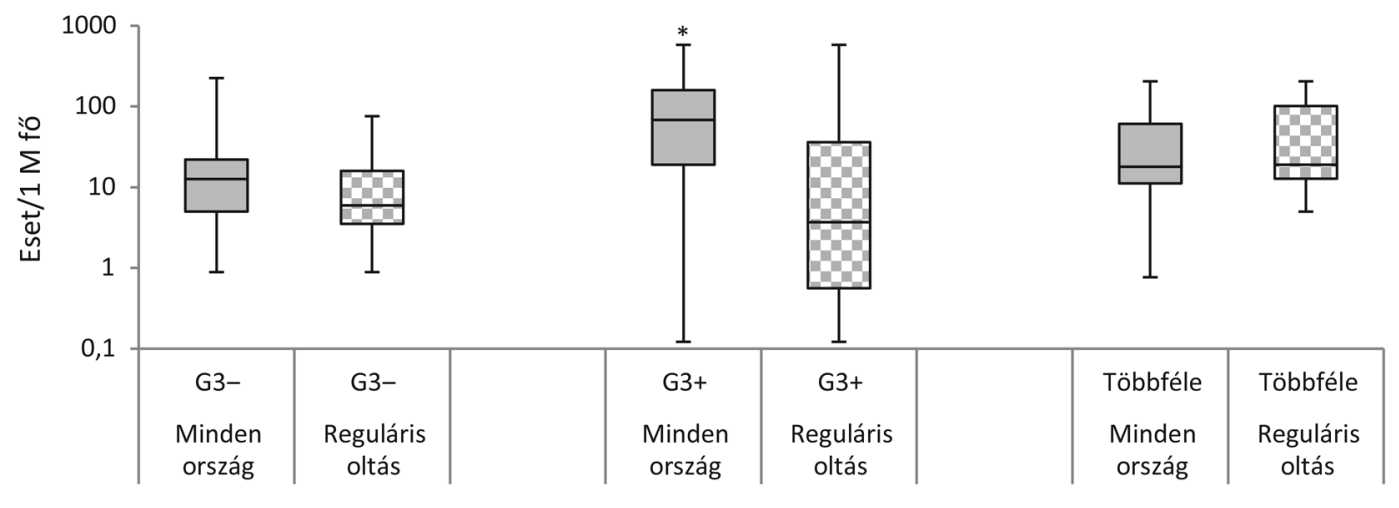

A BCG-oltás fajtája

5. ábra A járvány által érintett fertőzött személyek 1 millió lakosra vetített száma a BCG-vakcina típusa szerinti csoportosításban, azaz hogy az alkalmazott
vakcinatörzs tartalmazza-e a G3-epitóp-csoportot, vagy mutáció következtében elvesztette azt. A szürke oszlopok az összes ország mediánját, 25\%-os
és $75 \%$-os kvartilisét, illetve a minimális és maximális értéket ábrázolják; a halványan kockázott oszlopok azokat az országokat mutatják, ahol szabályos
oltási rend van érvényben, tehát az átoltottság jelentős
*p<0,05 szinten szignifikáns eltérés
BCG = Bacille Calmette-Guérin 


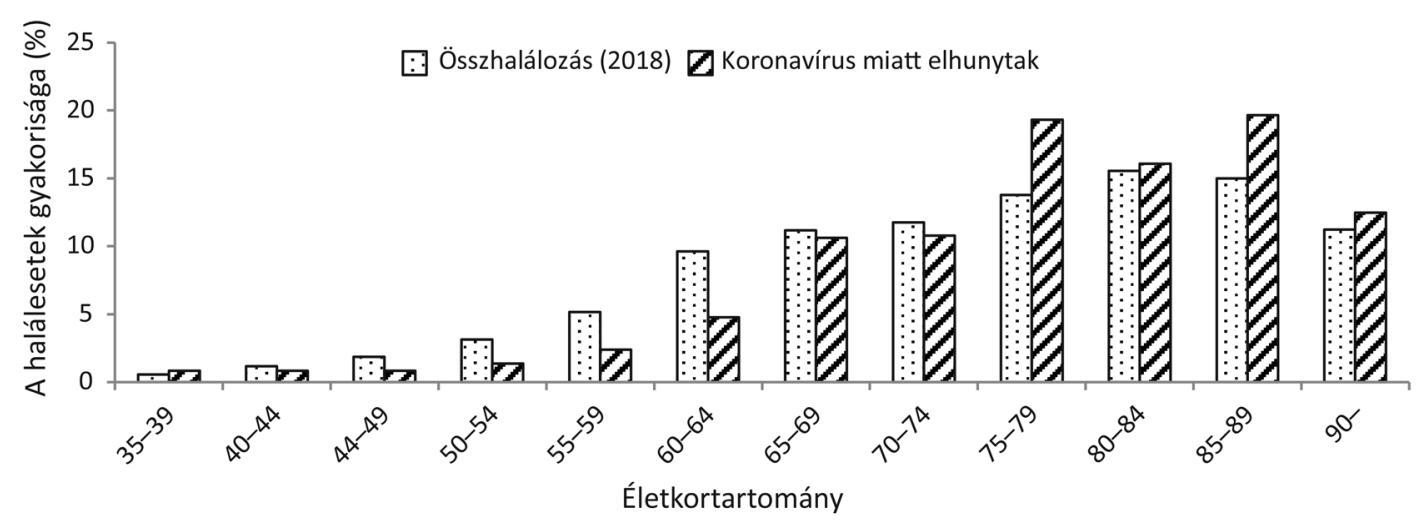

6. ábra

Magyarországon az egyes életkorcsoportokban a koronavírus következtében elhunyt személyek százalékos aránya (csíkos oszlopok), illetve a 2018. évben bekövetkezett halálesetek életkormegoszlása (pontozottan jelölt oszlopok). Látható, hogy az időskorban elhunyt emberek százalékos aránya megnőtt az előző évi kontrollidőszakhoz viszonyítva

adatforrás nem tartalmazza a 2020. január 22. előtti időszakot, arra nézve nincs információnk, de a görbék lefutása alapján tudható, hogy az első esetek jóval korábban jelenhettek meg Kína egyes tartományaiban.

A II. csoport országaiban szintén korán igazolták a vírus jelenlétét, az első haláleset azonban később jelentkezett. Jellemzően ezek az országok gazdaságilag fejlettek, komoly mértékű repülő- és hajóforgalmat bonyolítanak le (7. ábra), ami magyarázza a vírus korai megjelenését. Lehetséges, hogy az egy före jutó magas GDP biztosította a vírus korai észlelését, és a jó egészségügyi ellátás miatt az első halálesetek később jelentkeztek.

Végül is a vírus eljutott az világ szinte összes országába (III. csoport), a legkésőbb a gazdaságilag fejletlenebb régiókba (IV. csoport), ahol a koronavírussal összefüggő első haláleset is sokára jelent meg. Nehezen magyarázható viszont a 2. ábrán jelzett trend jelenléte a III. és a IV. csoportban. Elképzelhető, hogy bizonyos országok a járványt - bár korábban elindult - késve észlelték (esetleg a nem kellően szorgos tesztelés vagy adminisztrációs problémák miatt), esetleg csak akkor, amikor már halálos áldozat is volt. Emiatt tünhet úgy, hogy minél később észlelték a pozitív esetek megjelenését, annál rövidebb idő telt el az elsó észlelt pozitív eset és az első haláleset között.

Érdekes jelenség az is, hogy a járvány tetőzésének időpontja sok országban nagyjából egyszerre következett be (a 2020. március 21. utáni három hétben), a kezdő időponttól függetlenül. Talán azért, mert az év elején a vírus - országhatárokat átlépve - egységesen tudott terjedni, majd a nemzetközileg többé-kevésbé összehangolt járványügyi intézkedések közel egy időben szorították vissza. (Némileg eltérő álláspont tükröződik néhány európai ország intézkedéseivel kapcsolatban Árva és mtsai közleményében [36]).

Mindenképp elgondolkodtató - bár teljes körú magyarázatát nem leltük meg -, hogy miért tapasztalható viszonylag hosszú szünet a II. és a III. populáció között, azaz február első három hetében megállni látszott a vírus terjedése (2. ábra). Ekkor már az összes kontinensen jelen volt a járvány, így földrajzi, időjárási tényezők szere- pe nem valószínú. Inkább a vírusban magában történhetett olyan változás (mutáció), amely beindította az újabb, rohamos terjedést. Sajnos a kládokra vonatkozó adatok szigorú statisztikai elemzésére nincs módunk, így csak annyit mondhatunk, hogy a járvány kezdetén a 19A, 19B klád volt jellemző, melyeket később felváltott a 20A, 20B, 20C klád - ezek már hordozzák a virulenciát növelő D614G-mutációt [6].

A 3. ábra a BCG-vel való átoltottságot jelzi országcsoportonként. Szignifikánsnak az I. csoport adódik, azonban messzemenő következtetést ebból levonnunk nem szabad, hiszen ebbe a csoportba gyakorlatilag Kína tartományai tartoznak, ahol a BCG-átoltottság magas. Ellenpéldaként ide került azonban Franciaország és Olaszország is, ahol nem vakcinálnak. A II-IV. csoportban pedig nem látszik egyértelmű kapcsolat a BCG-oltással. Véleményünk szerint - a szignifikancia ellenére - a BCGvakcináció nem akadályozza meg a járvány korai betörését az adott országba, szerepe inkább a járvány későbbi alakulásában lehet.

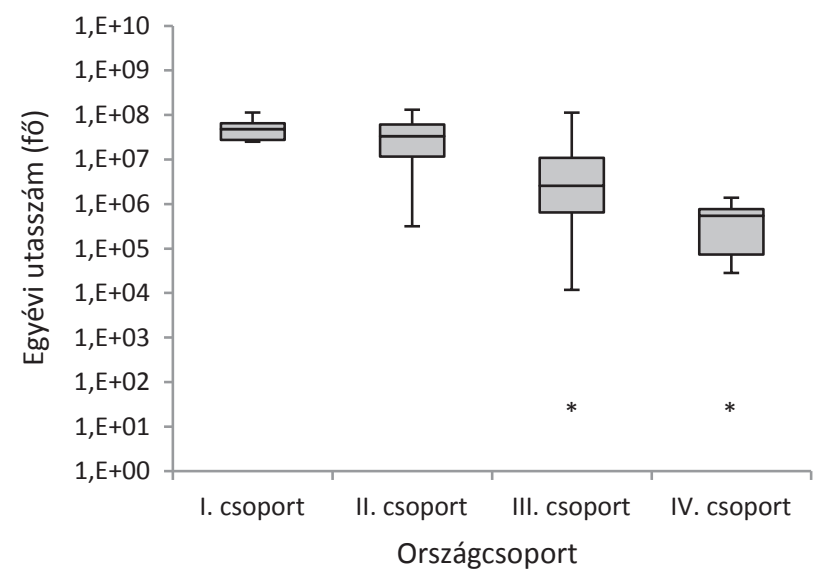

\begin{tabular}{l|l} 
7. ábra & A 2. ábrán meghatározott országcsoportokba tartozó országok
\end{tabular} repülőterein lebonyolított éves utasforgalom (fó) mediánja, 25\%-os és 75\%-os kvartilise, illetve minimális és maximális értéke

*A jelzett csoportok szignifikánsan $(\mathrm{p}<0,05)$ eltérnek az összes többi csoporttól (Dunn-teszt). A nagyobb légiforgalmat bonyolító országokban előbb jelent meg a vírusfertőzés 
Ezt támasztja alá, hogy a járvány kiterjedtségére jellemző paraméterek (napi maximális eset-, illetve halálozási szám, a tetőpontig észlelt esetek száma, illetve a június 30-ig észlelt összes eset száma) minden esetben szignifikánsan magasabb értéket mutatnak azokban az országokban, ahol sem jelenleg, sem régebben nem volt rendszeres BCG-védőoltás ( $4 / A$ és $4 / B$ ábra). Kézenfekvő magyarázat lehet, hogy a BCG-vakcina bizonyos védelmet nyújt a koronavírussal szemben. A szakirodalomban ezt már többen felvetették [14, 15, 17, 37-39], de kritikai észrevételeket is olvashatunk [40-43].

A WHO 2020. áprilisi állásfoglalása [44] nem ajánlja a BCG-oltások alkalmazását mint védekezési módot a koronavírus-fertőzéssel szemben: „Nincs bizonyíték arra, hogy a Bacille Calmette-Guérin-oltás (BCG) megóvja az embereket a COVID-19 vírusával való fertőzés ellen. Két, e kérdéssel foglalkozó klinikai vizsgálat van éppen folyamatban (megjegyzés: időközben további vizsgálatok is indultak), és a WHO a bizonyítékokat értékeli, amint rendelkezésre állnak. Bizonyítékok hiányában a WHO nem javasolja a BCG-oltást a COVID-19 megelőzésére."

Noha jelenleg is több mint 20 klinikai vizsgálat zajlik a BCG-oltás hatékonyságára vonatkozóan, ez idáig nem sikerült eldönteni a kérdést. Való igaz, hogy egyelőre még nagyon kevés idő telt el a koronavírus-járványból, ezért esetszintü megbízható adatok még nem is születhettek. Véleményünk kialakításakor óvatosnak kell lennünk, hogy ne kövessük el a „cum hoc ergo propter hoc” („vele, tehát miatta”) igen gyakori érvelési logikai hibát, hiszen abból, hogy két változó korrelál egymással, még nem következik az, hogy ok-okozati összefüggésben állnának. Akár egy harmadik, esetleg előttünk is rejtett közös ok is állhat a háttérben.

Igaz tehát, hogy a BCG-vakcinációt végző országokban a járvány első hulláma kevésbé volt súlyos, de ennek - az eddig taglaltakon kívül - más oka is lehet. Megfigyelhetjük, hogy az egy före jutó nemzeti össztermék (GDP) magasabb azokban az országokban, ahol sem a gyermekek, sem a felnőttek körében nem rendszeres a BCG-vakcináció (ábrán nem mutatjuk be). Tudott, hogy a tbc jellemzően a szegényebb országokat sújtotta, így ott volt nagy jelentősége a szigorú és rendszeres BCGvédőoltásnak. Megjegyzendő, hogy az országok korábbi társadalmi berendezkedése is eltérő. Például a volt szocialista országok, a szovjet utódállamok rendszerint alkalmazzák a BCG-oltást. A gazdasági tényezők erős befolyására Sarmadi és mtsai munkája is felhívja a figyelmet [45].

A BCG-vakcináció hatásmechanizmusával kapcsolatos további gondolat, hogy a vírus emberről emberre terjedését nemcsak az egyes emberek védettsége befolyásolhatja, hanem a vírust átadó beteg fertőzóképessége is. Az eddigi vizsgálatok az első tényezőre koncentráltak, ám nem zárható ki az sem, hogy a BCG-vakcináció a betegek vírusátadó képességét csökkenti. A kérdést célzott vizsgálatokkal lehetne eldönteni.
Úgy tünhet az 5. ábrán, mintha a G3+ típusú BCGvakcinát használó országokban a járvány nagyobb intenzitást ért volna el (ami a halálozási számokra is igaz). Közelebbről megvizsgálva azonban kiderül, hogy erős statisztikai összefüggés van ezen csoportosítás és a BCG szerinti csoportosítás között (khi-négyzet-próba, p = 0,003). Ennek háttere az, hogy a G3-vakcina használata azokra az országokra jellemző, ahol a gyerekeket és a felnőtteket is oltják, míg a G3+ vakcinát sok olyan ország használja, ahol a BCG-vakcináció csak esetleges. Ezért az előbbi csoportot külön is megvizsgáltuk, hiszen itt lehetne a vakcina hatása a legeróteljesebb. Végül azt tapasztaltuk, hogy sem az esetszámok, sem a halálozási jellemzők alakulására nincs hatása a BCG-vakcina típusának.

A halálozások életkorfüggését vizsgálva valóban megfigyelhető, hogy a koronavírus-betegségben elhunytak között sokkal több a 65 év feletti személy (89\%). Az adatok helyes értelmezéséhez azonban azt is figyelembe kell venni, hogy a népességben előforduló egyéb haláleset szintén gyakoribb ebben a korosztályban (78\%). Tény, hogy ez a különbség így is szignifikáns. Jogos tehát az a kijelentés, hogy az idősekre nézve veszélyesebb a koronavírus-fertőzés? A számok tükrében kijelenthetjük, hogy valóban veszélyesebb, bár a különbség korántsem hatalmas. A 65 éves kor feletti emberek koronavírus-halálozásra vonatkozó relatív kockázata a 65 év alattiakhoz képest 2,2 (95\% konfidenciaintervallum: 1,7-2,8). A férfi-nói különbségek pedig követik a halálozási adatokban egyébként is meglévő nemi eltéréseket (minimális női túlsúly).

Érdekes viszont a 6 . ábrán látható két kiugró oszlop. Az egyik a 75-79 éves korosztály. Ők azok, akik 1941 és 1945 között, tehát épp a második világháború alatt születtek. A másik kiemelkedő oszlop a 85-89 éveseké, akik épp az első magyarországi BCG-oltások (1936) előtti években születtek, és a későbbiekben sem részesültek az 1959-ben bevezetett, 3, 7, 10, 13, 17 és 20 éves fiatalokat érintő oltásokban. A 90 évesnél idősebbek között ez a különbség már csak elmosódottan látszik, talán az ebben az életkorban amúgy is magas halálozás miatt. Ezek az adatok semmiképpen sem bizonyítják a BCG-oltás hatékony védőszerepét, mégis felhívják a figyelmet erre a lehetôségre is.

A BCG-vakcina védőhatásával szembeni esetleges ellenérvet szolgáltathatnak a járvány halálozási rátájára vonatkozó becsléseink, melyek egymással jó összhangban vannak, mégsem mutatnak kapcsolatot sem a BCG-vakcináltsággal, sem a BCG-vakcina típusával. Sőt az egyes országcsoportok között sem látunk szignifikáns különbséget. Mivel tehát a megbetegedettek között a halálozás aránya már nem függ attól, hogy az országban alkalmaztak-e BCG-vakcinációt, úgy túnik, hogy a megbetegedettek kórlefolyására a vakcina nincs hatással. A halálozás alacsonyabb gyakorisága az oltott országokban a megbetegedések alacsonyabb számából fakad, és nem a betegség enyhébb lefolyásából ( $4 / A$ és $4 / B$ ábra).

Érdekes vizsgálatról számol be Dayal és mtsa [46] azokat az országokat vizsgálva, ahol kötelező BCG-újraoltá- 
sokat rendeltek el az elmúlt években. Ezekben az országokban kisebb volt a halálozási ráta, de a viszonyításul szolgáló országok kiválasztása nem szerencsés, ugyanis a járvány által erősen sújtott országok adatait vették alapul. Egy másik, megfontolásra érdemes probléma, amelyre maguk a szerzők is felhívták a figyelmet, az, hogy a járvány elején (esetükben 2020. március 29.) mért halálozási arány még nem megbízható. Mi a 2020. július l-jei adatainkon megismételve ezt az elemzést, hasonló eredményt kaptunk. A mi vizsgálataink szerint a halálozási arány 8,7\%-hoz képest csak 2,1\% a BCG-újraoltást alkalmazó országokban (a Dayal és mtsa által adott becslés szerint $5,3 \%$ és $0,6 \%$, ami ugyanazt a tendenciát mutatja). Erős kritikával kell azonban fogadnunk ezeket az eredményeket, mivel az országok más szempontokból is erősen különböznek egymástól.

A járvány lefolyását egy-egy országban nagyon sok tényező befolyásolja. Több szerző végzett sokparaméteres matematikai elemzéseket a BCG-vakcina hatásosságának igazolására [47], akár nagy mennyiségú változó figyelembevételével [34]. Ezek a bonyolult eljárások végül is igazolják a BCG-vakcinációval való statisztikai összefüggést, még ha az nem túl szoros is.

\section{Következtetés}

A 2-es típusú koronavírus okozta járvány még napjainkban is világszerte dúl. A járvány Európában való megjelenése és elterjedése során az első pár hónapban szembeötlő volt, hogy a terjedés sebessége és az átfertőződés mértéke kisebb azokban az országokban, ahol a tbc elleni védekezésül kiterjedt BCG-vakcinációt végeznek. Úgy tûnt, a fertőzés terjedése Európa közepén megállt egy hónapra, körülbelül a BCG-oltott országok határán. Utólag valószínúsíthető, hogy ez véletlen egybeesés, a vírusban zajlott le egy mutáció, ami új lendületet adott a járványnak. Az egyértelmúnek látszik, hogy a járvány terjedését az országok gazdasági fejlettsége, az utasforgalom nagysága (nyilván a kereskedelmi áruforgalom mértéke is) nagyban befolyásolja. Ezek a paraméterek Európában nem homogének, világviszonylatban vizsgálva pedig azt állapíthatjuk meg, hogy

- a BCG-vakcináció valószínúleg nem befolyásolja azt, hogy ha valaki már megbetegedett, akkor mekkora esélye van az életben maradásra, hiszen a megbetegedettek számára vonatkoztatott halálozás arányában szignifikáns különbséget nem tudtunk kimutatni;

- a BCG-vakcináltság valószínúleg nem befolyásolja a járvány kialakulásának időpontját;

- ugyanakkor kimutattuk, hogy minél kiterjedtebb a BCG-vakcináció egy országban, annál kevesebben fertőződtek meg a COVID-19-járvány első hulláma idején, és ezáltal az l millió lakosra vonatkozó halálozások száma is alacsonyabb volt.

Természetesen a fenti megállapításokban a BCGvakcinációval a direkt ok-okozati összefüggés nem bizonyítható.
Adataink a 2020. július 1-je előtti időszakra, tehát a járvány első hullámára vonatkoznak, a napjainkban kialakuló második, harmadik járványhullámok ilyen jellegú feldolgozása még adhat további információt a kérdés végleges megválaszolásához.

Anyagi támogatás: A közlemény megírása, illetve a kapcsolódó kutatómunka anyagi támogatásban nem részesült.

Szerzối munkamegosztás: P. Á.: Irodalmi áttekintés, adatelemzés. E.-K. B., D. G., P. S.: Adatgyújtés. M. M.: A cikk szövegezése. F. J.: Statisztikai elemzés, megfogalmazás. A cikk végleges változatát valamennyi szerző elolvasta és jóváhagyta.

Érdekeltségek: A szerzőknek nincsenek érdekeltségeik.

\section{Irodalom}

[1] Merkely B, Varga P, Kosztin A, et al. COVID-19 status in Hungary. [A COVID-19-járvány hazai története.] Orvosképzés 2020; 95: 438-445. [Hungarian]

[2] Váradi A, Ferenci T, Falus A. The coronavirus-induced COVID 19 pandemic. Previous experiences and scientific evidences at the end of March, 2020. [A koronavírus okozta COVID-19-pandémia. Korábbi tapasztalatok és tudományos evidenciák 2020. március végén.] Orv Hetil. 2020; 161: 644-651. [Hungarian]

[3] Szabó D, Ostorházi E, Kristóf K, et al. The structural characterization of SARS-CoV-2. [A SARS-CoV-2 strukturális jellemzése.] Orvosképzés 2020; 95: 446-449. [Hungarian]

[4] Kiss B, Kis Z, Pályi B, et al. Topography, spike dynamics and nanomechanics of individual native SARS-CoV-2 virions. BioRxiv 2020. 09. 17. Available from: https://doi.org/10.1101/ 2020.09.17.302380 [accessed: November 6, 2020].

[5] Thippareddi H, Balamurugan S, Patel J, et al. Coronaviruses - Potential human threat from foodborne transmission? Lebensm Wiss Technol. 2020; 134: 110147. Available from: https://doi. org/10.1016/j.lwt.2020.110147 [accessed: November 6, 2020].

[6] Zhang L, Jackson CB, Mou H, et al. The D614G mutation in the SARS-CoV-2 spike protein reduces Sl shedding and increases infectivity. BioRxiv 2020. 06. 12. Available from: https://doi. org/10.1101/2020.06.12.148726 [accessed: November 6, 2020].

[7] Daly JL, Simonetti B, Klein K, et al. Neuropilin-1 is a host factor for SARS-CoV-2 infection. Science 2020; 370: 861-865.

[8] Netea MG, Giamarellos-Bourboulis EJ, Domínguez-Andrés J, et al. Trained immunity: a tool for reducing susceptibility and severity of SARS-CoV-2 infection. Cell 2020; 181: 969-977.

[9] Zou X, Chen K, Zoul J, et al. Single-cell RNA-seq data analysis on the receptor ACE2 expression reveals the potential risk of different human organs vulnerable to $2019-\mathrm{nCoV}$ infection. Front Med. 2020; 14: 185-192.

[10] Udugama B, Kadhiresan P, Kozlowski HN, et al. Diagnosing COVID-19: the disease and tools for detection. ACS Nano 2020; 14: 3822-3835.

[11] Vásárhelyi B, Kristóf K, Ostorházi E, et al. The diagnostic value of rapid anti $\operatorname{IgM}$ and $\operatorname{IgG}$ detecting tests in the identification of patients with SARS-CoV-2 virus infection. [A specifikus IgM- és IgG-antitesteket detektáló gyorstesztek értéke a SARS-CoV-2 vírusfertőzés kimutatásában.] Orv Hetil. 2020; 161: 807-812. [Hungarian]

[12] Ragó Zs, Szijjártó L, Duda E, et al. Opportunity of periodic monitoring of COVID-19 patients, asymptomatic virus carriers, 
and postinfectious individuals with $\operatorname{IgM} / \operatorname{IgG}$ rapid antibody tests among healthcare workers during SARS-CoV-2 pandemic. [A COVID-19-betegek, tünetmentes hordozók, illetve a betegségen már átesettek periodikus monitorizálási lehetősége IgM/ IgG antitest alapú gyorstesztekkel az egészségügyi személyzet körében a SARS-CoV-2-járvány idején.] Orv Hetil. 2020; 161: 854-860. [Hungarian]

[13] Rényi G. Diagnostic value of rapid tests to detect SARS-CoV-2 infection. Letter to the editor. [Gyorstesztek értéke a SARSCoV-2-fertőzés kimutatásában. Levél a szerkesztőhöz.] Vásárhelyi B. Reply. [Válasz.] Orv Hetil. 2020; 161: 1391-1392. [Hungarian]

[14] Miller A, Reandelar MJ, Fasciglione K, et al. Correlation between universal BCG vaccination policy and reduced morbidity and mortality for COVID-19: an epidemiological study. MedRxiv 2020. 03. 24. Available from: https://doi.org/10.1101/ 2020.03.24.20042937 [accessed: November 6, 2020]. [Magyar nyelven referálta: Ruppert $\mathrm{M}$. A BCG védőoltás szerepe a COVID-19 elleni küzdelemben. Semmelweis Egyetem 2020; 21: 16.]

[15] Gursel M, Gursel I. Is global BCG vaccination-induced trained immunity relevant to the progression of SARS-CoV-2 pandemic? Allergy 2020; 75: 1815-1819.

[16] Netea MG, Quintin J, van der Meer JW. Trained immunity: a memory for innate host defense. Cell Host Microbe 2011; 9: 355-361

[17] Covián C, Retamal-Díaz A, Bueno SM, et al. Could BCG vaccination induce protective trained immunity for SARS-CoV-2? Front Immunol. 2020; 11: 970.

[18] Moorlag SJ, Arts RJ, van Crevel R, et al. Non-specific effects of BCG vaccine on viral infections. Clin Microbiol Infect. 2019; 25: $1473-1478$

[19] Erdei A, Sármay G, Prechl J. (eds.) Immunology. [Immunológia.] Medicina Könyvkiadó, Budapest, 2012. [Hungarian]

[20] Sakula A. Robert Koch Centenary of the discovery of the tubercle bacillus, 1882. Can Vet J. 1983; 24: 127-131.

[21] Koch R. The etiology of tuberculosis. [Die Aetiologie der Tuberculose.] Berl Klin Wochenschr. 1882; 19: 221-230. [German]

[22] Huebner RE. BCG vaccination in the control of tuberculosis. In: Shinnick TM. (ed.) Tuberculosis. Springer, Berlin, Heidelberg, 1996; pp. 263-282

[23] Cernuschi T, Malvolti S, Nickels E, et al. Bacillus Calmette-Guérin (BCG) vaccine: a global assessment of demand and supply balance. Vaccine 2018; 36: 498-506.

[24] Luca S, Mihaescu T. History of BCG vaccine. Maedica (Buchar). 2013; 8: 53-58

[25] Mivasaka $M$. Is BCG vaccination causally related to reduced COVID-19 mortality? EMBO Mol Med. 2020; 12: el2661

[26] Ritz N, Dutta B, Donath S, et al. The influence of Bacille Calmette-Guérin vaccine strain on the immune response against tuberculosis. A randomized trial. Am J Respir Crit Care Med. 2012; 185: 213-222.

[27] Zhang W, Zhang $\mathrm{Y}$, Zheng H, et al. Genome sequencing and analysis of BCG vaccine strains. PLoS ONE 2013; 8: e71243.

[28] Lakatos K. A historical overview of the fight against tuberculosis. [A tuberkulózis elleni küzdelem történeti áttekintése.] Jászkunság 1964; 10: 18-22. [Hungarian]

[29] Weissfeiler Gy. Issues of tuberculosis vaccination. [A tuberkulózis elleni védőoltások kérdései.] Orv Hetil. 1962; 103: 1009-1014. [Hungarian]

[30] Lugosi L. Results of the BCG vaccination in Hungary since 1929. Evaluation of preventive and immunotherapeutic effectiveness. [A BCG vakcináció eredményei Magyarországon 1929 től. A preventív és immunterápiás alkalmazás értékelése.] Orv Hetil. 1998; 139: 1563-1570. [Hungarian]
[31] Flesch I. BCG vaccination in Budapest. [BCG-oltások Buda pesten.] Orv Hetil. 1962; 103: 1023-1029. [Hungarian]

[32] Abubakar I, Pimpin L, Ariti C, et al. Systematic review and metaanalysis of the current evidence on the duration of protection by bacillus Calmette-Guérin vaccination against tuberculosis. Health Technol Assess. 2013; 17: 1-372.

[33] Nguipdop-Djomo P, Heldal E, Rodrigues LC, et al. Duration of BCG protection against tuberculosis and change in effectiveness with time since vaccination in Norway: a retrospective population-based cohort study. Lancet Infect Dis. 2016; 16: 219-226.

[34] Sala G, Chakraborti R, Ota A, et al. Association of BCG vaccination policy and tuberculosis burden with incidence and mortality of COVID-19. MedRxiv 2020. 03. 30. Available from: https:// doi.org/10.1101/2020.03.30.20048165 [accessed: November $6,2020]$.

[35] Deslandes A, Berti V, Tandjaoui-Lambotte Y, et al. SARS-CoV-2 was already spreading in France in late December 2019. Int J Antimicrob Agents 2020; 55: 106006.

[36] Árva D, Mészáros Á, Szarvas Zs, et al. Situation report about the novel coronavirus outbreak in Hungary: Comparison of the timeline and effectiveness of public health measures with those in other European countries. [A magyarországi koronavírus-járvány alakulása és a meghozott intézkedések idóbeliségének és eredményességének összehasonlítása más európai országokkal.] Orvosképzés 2020; 95: 450-459. [Hungarian]

[37] O'Connor E, Teh J, Kamat AM, et al. Bacillus Calmette-Guérin (BCG) vaccination use in the fight against COVID-19. What's old is new again? Future Oncol. 2020; 16: 1323-1325.

[38] Hegarty P, Kamat A, Zafirakis H, et al. BCG vaccination may be protective against Covid-19. March 2020. Available from: https://doi.org/10.13140/RG.2.2.35948.10880 [accessed: November 6, 2020].

[39] Ozdemir C, Kucuksezer UC, Tamay ZU. Is BCG vaccination affecting the spread and severity of COVID-19? Allergy 2020; 75: 1824-1827.

[40] Kantor IN. BCG versus COVID-19? Medicina (B Aires) 2020; 80: 292-294.

[41] Kumar J, Meena J. Demystifying BCG vaccine and COVID-19 relationship. Indian Pediatr. 2020; 57: 588-589.

[42] Riccò M, Gualerzi G, Ranzieri S, et al. Stop playing with data: there is no sound evidence that Bacille Calmette-Guérin may avoid SARS-CoV-2 infection (for now). Acta Biomed. 2020; 91 : 207-213.

[43] Szigeti R, Kellermayer D, Kellermayer R. BCG protects against COVID-19? A word of caution. MedRxiv 2020. 04. 09. Available from: https://doi.org/10.1101/2020.04.09.20056903 [accessed: November 6, 2020].

[44] World Health Organization. Bacille Calmette-Guérin (BCG) vaccination and COVID-19: scientific brief, 12 April 2020. WHO, Geneva, 2020. Available from: https://apps.who.int/ iris/handle/10665/331745 [accessed: November 6, 2020].

[45] Sarmadi M, Marufi N, Kazemi Moghaddam V. Association of COVID-19 global distribution and environmental and demographic factors: an updated three-month study. Environ Res. 2020; 188: 109748.

[46] Dayal D, Gupta S. Connecting BCG vaccination and COVID-19. Additional data. MedRxiv 2020. 04. 07. Available from: https:// doi.org/10.1101/2020.04.07.20053272 [accessed: November $6,2020]$.

[47] Macedo A, Febra C. Relation between BCG coverage rate and COVID-19 infection worldwide. Med Hypotheses 2020; 142: 109816.

(Fent János dr., Budapest, Róbert K. krt. 44., 1134 e-mail: stjano@freemail.hu) 